\title{
UNDERSTANDING ON STRATEGIES OF TEACHING MATHEMATICAL PROOF FOR UNDERGRADUATE STUDENTS
}

\author{
Syamsuri ${ }^{1, *}$, Indiana Marethi ${ }^{1}$, and Anwar Mutaqin ${ }^{1}$ \\ ${ }^{1}$ FKIPUniversitas Sultan Ageng Tirtayasa, Indonesia \\ *e-mail:syamsuri@untirta.ac.id
}

\begin{abstract}
Many researches revealed that many students have difficulties in constructing proofs. Based on our empirical data, we develop a quadrant model to describe students' classification of proof result. The quadrant model classifies a students' proof construction based on the result of mathematical thinking. The aim of this article is to describe a students' comprehension of proof based on the quadrant model in order to give appropriate suggested learning. The research is an explorative research and was conducted on 26 students majored in mathematics education in public university in Banten province, Indonesia. The main instrument in explorative research was researcher itself. The support instruments are provingtask and interview guides. These instruments were validated from two lecturers in order to guarantee the quality of instruments.Based on the results, some appropriate learning activities should be designed to support the students' characteristics from each quadrant, i.e: a hermeneutics approach, using the twocolumn form method, learning using worked-example, or using structural method.
\end{abstract}

Keywords: proof, proving learning, undergraduate, quadrant model

\section{MEMAHAMI STRATEGI PENGAJARAN PEMBUKTIAN MATEMATIS DI PERGURUAN TINGGI}

\begin{abstract}
Abstrak: Banyak peneliti pendidikan matematika menyatakan bahwa siswa mengalami kesulitan dalam mengonstruksi bukti. Berdasarkan kajian empiris, penulis membangun suatu model kuadran untuk mendeskripsikan kategori konstruksi bukti yang dibangun siswa. Model kuadran tersebut mengklasifikasikan konstruksi bukti berdasarkan cara berpikir matematis saiwa. Adapun tujuan dari artikel ini ialah mendeskripsikan pemahaman siswa dalam mengonstruksi bukti berdasarkan model kuadran serta memberikan saran strategi pembelajarannya. Penelitian ini merupakan penelitian eksploratif yang melibatkan 26 mahasiswa Jurusan Pendidikan Matematika pada universitas negeri di Provinsi Banten. Instrumen utama dalam penelitian eksploratif adalah peneliti sendiri. Instrumen pendukungnya ialah tugas pembuktian matematis dan panduan wawancara. Kedua instrumen pendukung tersebut telah divalidasi untuk menjamin kualitas instrumen yang digunakan. Hasil penelitian ini memberikan saran terkait aktivitas pembelajaran yang seharusnya dilakukan oleh pengajar agar sesuai dengan karakteristik berpikir siswa dalam mengonstruksi bukti pada masing-masing kuadran, misalnya : pendekatan heurmenistik, menggunakan metode dua-kolom, pembelajaran worked-example ataupun menggunakan metode terstruktur.
\end{abstract}

Kata Kunci: bukti, pengajaran bukti, mahasiswa, model kuadran

\section{INTRODUCTION}

Proof and proving in mathematics education are an important part of mathematics, as a pillar of the mathematics building. Therefore, mathematics education especially in mathematics learning in university emphasizes the constructing of mathematical proof. Students who enter college level should develop a formal mathematical knowledge.
Many researchers have investigated about mathematical proving and its learning. Some researchers wrote about students' proof schemes for mathematical proving (Iannone, Inglis, MejíaRamos, Simpson, \& Weber, 2011; Lee, 2016; Syamsuri \& Santosa, 2017). And another ones wrote about thinking process in proof production (Weber \& Alcock, 2004; Sean Larsen \& Zandieh, 2008; Stylianides \& Stylianides, 2009; Syamsuri, Purwanto, Subanji, \& Irawati, 2017) and its 
material learning (Fadillah \& Jamilah, 2016). It is indicated that teaching mathematical proof is important in mathematics education.

Students are introduced to formal proof in the study of mathematics at university. Formal proof as a process begins from explicit quantified definitions and deduces that other properties hold as a consequence (Tall et al., 2012). Learning how to construct formal proof is given to make sense a formal definition that can be used in building the basis of deduction theorem. It is indicated that undergraduate students must develop their mathematics knowledge formally. A formal proof is based on rigorous logic and can be communicated like a discussion of mathematicians on scientific forum. Therefore, undergraduate students need proving exercises so that they will able to understand a formal mathematics structure.

The process of proving a mathematical proposition is a sequence of mental and physical actions, such as writing, thinking tobegin the proof, draw diagrams, to reflect on previous actions or trying to remember the example. The process of proof formation of a theorem of or statement is more complex than the proof itself (Selden \& Selden, 2003). Therefore, teacher is needed for facilitating in learning mathematics thus facilitate students in mathematical proofs. In mathematics, one of the teachers'aid to help the students in order to make it easy to perform mathematical proofs is to make it into a tangible proof (Sowder \& Harel, 2003). So, teaching assistance on mathematical proof to the students can be done gradually and trying to create proof into something tangible.

Many researches revealed that many students have difficulties in constructing proofs (Moore, 1994; Baker \& Campbell, 2004; Weber, 2001). Moore stated that there are 7 difficulties in mathematical proving, i.e.: the students (1) did not know the definitions, (2) had little intuitive understanding of the concepts, (3) had inadequate concept images for doing the proofs, (4) were unable, or unwilling, to generate and use their own examples, (5) were unable to understand and use mathematical language and notation, (6) did not know how to use definitions to obtain the overall structure of proofs, and (7) did not know how to begin proofs. Meanwhile, Baker and Campbell (2004) explained that students' difficulties in proving were caused by some factors, i.e.: (1) understanding of the rules and nature of proof, (2) conceptual understanding, (3) proof techniques and strategies, and (4) cognitive load. In addition, Weber (2001) asserted that: (1) students' difficulties included their misunderstanding of a theorem or a concept and misapplying it, (2) students' inadequate conception knowledge about mathematical proof, and (3) students' inadequacy in developing strategies for proof. Therefore, the difficulties that students face consist of uncompleted conceptual understanding and incorrect proving strategy.

Another research was revealed a proof assessment instruments. Andrew created The Proof Error Evaluation Tools (PEET) to assess a students' proof. A PEET consists of proof structure and conceptual understanding (Andrew, 2009). And also, Mejia-Ramos et al. (2012) developed an assessment model for proof comprehension in undergraduate mathematics. They stated that the model described ways to assess students' understanding of seven different aspects of a proof. These types of assessment are: (1) Meaning of terms and statements, (2) Logical status of statements and proof framework, (3) Justification of claims, (4) Summarizing via high-level ideas, (5) Identifying the modular structure, (6) Transferring the general ideas or methods to another context, and (7) Illustrating with examples. Therefore, the assessment consists of conceptual understanding and proving strategy. Based on our empirical data, we develop a quadrant model to describe students' classification of proof production. Figure 1 describes the quadrant model.

The quadrant model classifies a students' proof construction based on result of mathematical thinking. Therefore, investigation of thinking process or outcome of thinking process is necessary for selecting an appropriate learning strategies. Many prior researches revealed outcome thinking process about proof construction. For instance, a students have difficulties in proof construction (Moore, 1994; Gibson, 1998; Baker \& Campbell, 2004; Weber, 2006) and so students made errors in proof construction (Selden \& Selden, 2003; Sowder \& Harel, 2003). Nevertheless, researches which reveal mental structures and mental mechanisms are rarely found. Whereas knowing students' thinking process that consisting of both mental structures and mental mechanisms 
can help teachers or lecturers in order to give an appropriate learning assistance. Some suitable learning activities should be designed to support the construction of this thinking process. In addition, if students' thinking process is incorrect, then refinement thinking process can be easy in order to it does not occur in next learning.

In this article, we will describe a students' comprehension of proof based on quadrant model in Figure 1.

\section{RESEARCH METHOD Participants}

The research was conducted on 26 students majored in mathematics education in public university at Banten province, Indonesia. The consideration of that was because the students were able to think a formal proof in mathematics. And also, the students are more easily managed by the researcher to follow the procedures empirically planned, so that the data obtained is a students' actual of reflection thinking. Giving a proving-question in the beginning, aim to select students who will be the subjects, which further deepened with the interview. The diagram of selecting research subject is Figure 2.

\section{Instruments}

The main instrument in explorative research was researcher itself. The support instruments are proving-task and interview guides. These instruments were evaluated and validated from two lecturers in order to guarantee the quality of instruments. The interview is open and it's needed to reveal students' response about proof comprehension. Procedures to obtain data are 1) subject is given the task proving and asked him/her to accomplish the task by think-aloud. And then 2) subject is interviewed based onthe-task. Therefore, the scratch of proving-task and transcript of the interview is obtained. The proving-task is in the following.

Prove: For any positive integer $m \& n$, if $m^{2}$ and $n^{2}$ are divisible by 3 , then $m+n$ is divisible by 3 .

We used this task because some methods can be used for solving, i.e.: direct proof, contradiction, and contrapositive. Besides, we would like to test students' comprehension about mathematical induction method, because some students have an opinion that using mathematical induction to prove a number which is "divisible by 3 ".

The interview guides is created for confirmation and clarification about students' proof comprehension. According to MejiaRamos et al. (2012) we compile the interview questions, i.e.: (1) What mathematical concepts that are used in the proving task? Explain. (2) How do you accomplish the task? (3) Why do you argue with this step?, (4) What is the big idea in your proof construction?, (5) What mathematical proposition that supports your proof construction?, (6) Would you like to give an example of the task?, and (7) In the task, if number " 3 " is replaced by " 4 ", what is your opinion?

\begin{tabular}{|c|c|}
\hline $\begin{array}{l}\text { Quadrant II Proof-structure } \\
\text { Insufficient concept in formal-proof } \\
\text { construction } \\
\text { - An error caused important parts of the } \\
\text { proof to be left unaddressed. } \\
\text { - False statement or incorrect computation in } \\
\text { the proof }\end{array}$ & $\begin{array}{l}\text { Quadrant I } \\
\text { Correct Proof Construction } \\
\text { - Correct in Proof-structure } \\
\text { - Correct in Conceptual Understanding }\end{array}$ \\
\hline $\begin{array}{l}\text { Quadrant III } \\
\text { Insufficient concept and Incorrect proof- } \\
\text { structure in formal-proof construction } \\
\text { - The proof contained extraneous details or } \\
\text { steps that did not really contribute to the } \\
\text { proof. } \\
\text { - False statement or incorrect computation in } \\
\text { the proof } \\
\text { - Incorrectly claimed that one statement } \\
\text { implied or equaled another statement. }\end{array}$ & $\begin{array}{l}\text { Quadrant IV } \\
\text { Incorrect proof-structure in formal-proof } \\
\text { construction } \\
\text { - The approach taken in proving a statement } \\
\text { will not work } \\
\text { - The proof was to be completed using a } \\
\text { specific method, but this method was not } \\
\text { used. } \\
\text { - False statement or incorrect computation in } \\
\text { the proof }\end{array}$ \\
\hline
\end{tabular}

Figure 1. Quadrant model of students formal-proof construction (Syamsuri, Purwanto, Subanji, \& Irawati, 2016) 


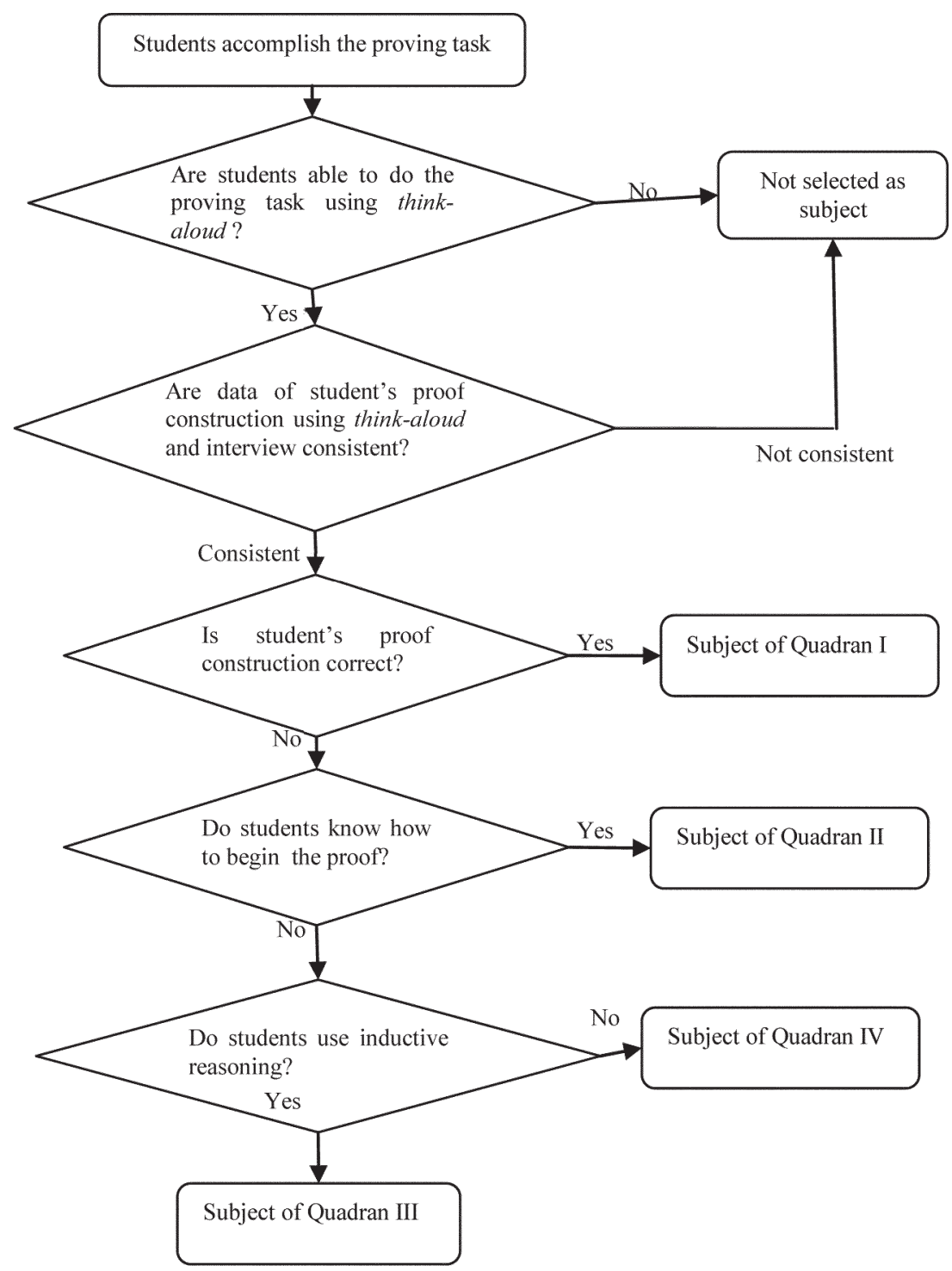

Figure 2 - Process of selecting subject

\section{RESULTS AND ANALYSIS \\ Results}

The following are the description of the data of the failures experienced by students. The tool used in the evaluation of the proofs was the Error Proof Evaluation Tools (PEET) developed by Andrew (2009).

The most frequent errors were an error in claiming a statement, the error in making a statement, and one in choosing a proof type. Errors in claims occurred at the beginning of proof by stating $n^{2}=(3 a)^{2}$, with $a$ is an integer. The error in choosing a proof type was by choosing an incorrect method.

Based on PEET results, students' response can be further classified into three categories. First, there are 6 students who are wrong in extracting a concept so become wrong in expressing formal proof (corresponding to U4-2 and U5-1 on Table 1 and 2). Secondly, as many as 10 students less likely to complete in deepening the concept, so there is a missing piece of concept (corresponding to S2, S3, U4-1, U5-1 and U5-2 on Table 1 and 2). Finally, there are 5 students who committed errors in selecting methods of proof in the initial stage of logic verification (corresponding to S1-2, S2, and S7-1 on Table 1 and 2). Therefore, of the 26 students who were given the task of mathematical proof, there were 5 students, 6 students, 10 students and 5 students in Quadrant I, Quadrant II, Quadrant III and Quadrant IV, respectively. We will describe characteristics of proof comprehension of S1, S2, S3, and S4 as subjects in Quadrant I, Quadrant II, Quadrant III and Quadrant IV, respectively. The students' proof construction is below. 
Table 1. Students' error on proof-structure (S) in constructing formal proof

\begin{tabular}{|c|c|c|c|}
\hline No & $\begin{array}{l}\text { Element of Proof } \\
\text { Structure }\end{array}$ & Component Descriptions & $\begin{array}{l}\text { Number of Students } \\
\text { who made error }\end{array}$ \\
\hline \multirow[t]{3}{*}{1} & Proof setup & $\begin{array}{l}\text { S1. Introduced variables without defining them or performed operations } \\
\text { that were undefined. }\end{array}$ & 8 \\
\hline & & S1. The approach taken in proving a statement will not work. & 10 \\
\hline & & $\begin{array}{l}\text { S1. The proof was to be completed using a specific method, but this } \\
\text { method was not used. }\end{array}$ & 10 \\
\hline 2 & Assumption & S2. Made a false assumption somewhere in the proof. & 15 \\
\hline 3 & $\begin{array}{l}\text { Linear/sequential } \\
\text { order }\end{array}$ & $\begin{array}{l}\text { S3. Didn't proceed through the proof in a linear fashion, and ideas } \\
\text { were not in logical order. }\end{array}$ & 10 \\
\hline \multirow[t]{2}{*}{4} & $\begin{array}{l}\text { Stray details/ } \\
\text { conciseness }\end{array}$ & $\begin{array}{l}\text { S4. The proof contained extraneous details or steps that did not really } \\
\text { contribute to the proof. }\end{array}$ & 6 \\
\hline & & $\begin{array}{l}\text { S4. The length of the proof was unnecessarily long and thus extremely } \\
\text { difficult to follow. }\end{array}$ & 2 \\
\hline 5 & Neat presentation & $\begin{array}{l}\text { S5. The write-up was illegible at times, making it difficult to read } \\
\text { and/or understand. }\end{array}$ & 0 \\
\hline 6 & Technology's place & $\begin{array}{l}\text { S6. Relied too much on calculator or computer-generated information } \\
\text { in one step of the proof. }\end{array}$ & 0 \\
\hline \multirow[t]{2}{*}{7} & Proof type & $\begin{array}{l}\text { S7. Needed to show } \mathrm{p} \rightarrow \mathrm{q} \text { but did not show directly, or by }-\mathrm{q} \rightarrow-\mathrm{p} \text {, } \\
\text { or by contradiction }\end{array}$ & 15 \\
\hline & & $\begin{array}{l}\text { S7. Only gave an example to establish the truth of a mathematical } \\
\text { statement. }\end{array}$ & 10 \\
\hline 8 & $\begin{array}{l}\text { Correct use of } \\
\text { symbols/notation }\end{array}$ & S8. Used nonstandard or confusing notation. & 0 \\
\hline
\end{tabular}

Table 2. Students' error on conceptual-understanding $(\mathbf{U})$ in constructing formal proof

\begin{tabular}{|c|c|c|c|}
\hline No & $\begin{array}{c}\text { Element of } \\
\text { Mathematical } \\
\text { Concept }\end{array}$ & Component Descriptions & $\begin{array}{l}\text { Number of Students } \\
\text { who made error }\end{array}$ \\
\hline 1 & Sufficient details & U1. Wrote a statement that was not justified, explained, or verified. & 10 \\
\hline 2 & Clarity & $\begin{array}{l}\text { U2. Wrote a statement or paragraph that was ambiguous, confusing, } \\
\text { and/or unnecessarily complex. }\end{array}$ & 3 \\
\hline \multirow[t]{2}{*}{3} & Pictures in the proof & $\begin{array}{l}\text { U3. Failed to include an illustrative picture that would make the } \\
\text { proof easier to understand. }\end{array}$ & 0 \\
\hline & & U3. Relied too much on a picture to prove something was true. & 0 \\
\hline \multirow[t]{2}{*}{4} & $\begin{array}{l}\text { Crucial step/main } \\
\text { idea }\end{array}$ & U4. Did not sufficiently justify a crucial step in the proof. & 18 \\
\hline & & $\begin{array}{l}\text { U4. An error caused important parts of the proof to be left } \\
\text { unaddressed. }\end{array}$ & 10 \\
\hline \multirow[t]{2}{*}{5} & $\begin{array}{l}\text { Correct implications } \\
\text { and statements }\end{array}$ & U5. Made a false statement or incorrect computation in the proof. & 21 \\
\hline & & $\begin{array}{l}\text { U5. Incorrectly claimed that one statement implied or equaled } \\
\text { another statement. }\end{array}$ & 21 \\
\hline 6 & All cases present & U6. Included some cases but not others (which were not trivial). & 1 \\
\hline
\end{tabular}

Students' proof construction depends on their understanding about the proving task. A different proof construction among students indicated that the understanding of proof is different too. Subject S1 knew how to begin the proof. And also, he could connect to appropriate mathematical concepts well. Subject S2 knew how to begin the proof, but he fails in connecting mathematical concept. Subject S3 didn't know how to begin the proof, and so she solves the proving task using inductive reasoning. Subject S4 didn't know how to begin the proof, and so she fails in beginning a proof. Therefore, we suggest that the proof comprehension of these students 
Table 3. Students' proof comprehension

\begin{tabular}{|c|c|c|c|c|c|}
\hline No. & $\begin{array}{c}\text { Component } \\
\text { of Proof } \\
\text { Comprehension }\end{array}$ & Subject S1 & Subject S2 & Subject S3 & Subject S4 \\
\hline 1 & $\begin{array}{l}\text { Logical status of } \\
\text { statements and } \\
\text { proof framework }\end{array}$ & $\begin{array}{l}\text { Direct proof } \\
\text { Using congruent } \\
\text { modulo number }\end{array}$ & $\begin{array}{l}\text { Direct proof } \\
\text { Using congruent } \\
\text { modulo number }\end{array}$ & Inductive reasoning & $\begin{array}{l}\text { Direct proof } \\
\text { Failure in beginning } \\
\text { a proof }\end{array}$ \\
\hline 2 & $\begin{array}{l}\text { Justification of } \\
\text { claims }\end{array}$ & $\begin{array}{l}\text { Create } 5 \text { correct } \\
\text { claims }\end{array}$ & $\begin{array}{l}\text { Create a correct claim } \\
\text { and an incorrect } \\
\text { claim }\end{array}$ & $\begin{array}{l}\text { Create only a clarified } \\
\text { claim }\end{array}$ & $\begin{array}{l}\text { Create an incorrect } \\
\text { claim in beginning } \\
\text { proof }\end{array}$ \\
\hline 3 & $\begin{array}{l}\text { Meaning of terms } \\
\text { and statements }\end{array}$ & $\begin{array}{l}\text { - } \text { Integer } \\
\text { - } \text { quadratic number } \\
\text { - number that } \\
\text { divisible by } 3 \\
\text { - congruent modulo } \\
\text { number }\end{array}$ & $\begin{array}{l}\text { - } \text { integer } \\
\text { - quadratic number } \\
\text { - number that } \\
\text { divisible by } 3 \\
\text { - congruent modulo } \\
\text { number }\end{array}$ & $\begin{array}{l}\text { - } \text { integer } \\
\text { - number that } \\
\text { divisible by } 3 \\
\text { - simple description } \\
\text { of concepts }\end{array}$ & $\begin{array}{l}\text { - } \text { integer } \\
\text { - number that } \\
\text { divisible by } 3 \\
\text { - adequacy of } \\
\text { concept image }\end{array}$ \\
\hline 4 & $\begin{array}{l}\text { Summarizing via } \\
\text { high-level ideas }\end{array}$ & $\begin{array}{l}\text { - Showed that if } \\
\text { both } m^{2} \text { and } n^{2} \text { are } \\
\text { divisible by } 3 \text { then } \\
m^{2}-n^{2} \text { is divisible } \\
\text { by } 3 \\
\text { - Showed that if } m^{2} \text { - } \\
n^{2} \text { is divisible by } 3 \\
\text { then }(m+n)(m-n) \text { is } \\
\text { divisible by } 3 \\
\text { - Showed that if } \\
(m+n)(m-n) \text { is } \\
\text { divisible by } 3 \text { then } \\
m+n \text { is divisible } \\
\text { by } 3\end{array}$ & $\begin{array}{l}\text { - Showed that if } \\
\text { both } m^{2} \text { and } n^{2} \text { are } \\
\text { divisible by } 3 \text { then } \\
m^{2}-n^{2} \text { is divisible } \\
\text { by } 3 \\
\text { - Showed that if } m^{2}- \\
n^{2} \text { is divisible by } 3 \\
\text { then }(m+n)(m-n) \text { is } \\
\text { divisible by } 3\end{array}$ & - Not appeared & $\begin{array}{l}\text { - Define that } m=3 a \\
\text { - Define that } n=6 a \\
\text { - Verified that } m^{2} \text { is } \\
\text { divisible by } 3 \\
\text { - Verified that } n^{2} \text { is } \\
\text { divisible by } 3 \\
\text { - Verified that } m+n \\
\text { is divisible by } 3\end{array}$ \\
\hline 5 & $\begin{array}{l}\text { Identifying the } \\
\text { modular structure }\end{array}$ & $\begin{array}{l}\text { There are some } \\
\text { theorems } \\
\text { - If } \mathrm{a} \mid \mathrm{b} \text { and } \mathrm{a} \mid \mathrm{c} \text { then } \\
\mathrm{a}|\mathrm{b}-\mathrm{c}, \mathrm{a}| \mathrm{b}+\mathrm{c} \\
\text { - If } \mathrm{c} \mid \mathrm{ab} \text { then } \mathrm{c} \mid \mathrm{a} \text { or } \\
\mathrm{c} \mid \mathrm{b}\end{array}$ & - Not appeared & Not appeared & - Not appeared \\
\hline 6 & $\begin{array}{l}\text { Illustrating with } \\
\text { examples }\end{array}$ & $\begin{array}{l}\text { - Give an example } \\
\text { that } m^{2}=6^{2} \text { and } \\
n^{2}=3^{2}\end{array}$ & $\begin{array}{l}\text { Failure in giving } \\
\text { an example; } m=2 \\
\text { and } n=7, \text { because } \\
\text { he believe that } \\
\text { the proposition is } \\
\text { incorrect }\end{array}$ & $\begin{array}{l}\text { - } m=6 \text { and } n=3 \text {, but } \\
\text { she determined } m \\
\text { and } n \text { before } m^{2} \\
\text { and } n^{2} .\end{array}$ & $\begin{array}{l}\text { - She stated that } \\
\text { the proposition is } \\
\text { incorrect because } \\
\text { not all of } m^{2} \text { and } n^{2} \\
\text { is divisible by } 3 \text {. }\end{array}$ \\
\hline 7 & $\begin{array}{l}\text { Transferring the } \\
\text { general ideas } \\
\text { or methods to } \\
\text { another context }\end{array}$ & $\begin{array}{l}\text { Before reflective } \\
\text { thinking, he stated } \\
\text { that "If both } m^{2} \text { and } n^{2} \\
\text { are divisible by } 4 \text { then } \\
m+n \text { is divisible by } 4 \text { " } \\
\text { is correct proposition, } \\
\text { nevertheless when } \\
\text { asked to give an } \\
\text { example, he gave } \\
m=2 \text { and } n=4 \text { that is } \\
\text { a counter-example } \\
\text { of the proposition. } \\
\text { Immediately, S1 } \\
\text { aware a failure } \\
\text { and stated that } \\
\text { the proposition is } \\
\text { incorrect }\end{array}$ & $\begin{array}{l}\text { S2 stated that "If } \\
\text { both } m^{2} \text { and } n^{2} \text { are } \\
\text { divisible by } 4 \text { then } \\
m+n \text { is divisible } \\
\text { by } 4 \text { " is incorrect } \\
\text { proposition, because } \\
\text { the before proposition } \\
\text { is incorrect. In } \\
\text { addition, S } 2 \text { tried } \\
m=2 \text { and } n=4 \text { that is } \\
\text { a counter-example of } \\
\text { the proposition. }\end{array}$ & $\begin{array}{l}\text { S3 stated that "If } \\
\text { both } m^{2} \text { and } n^{2} \text { are } \\
\text { divisible by } 4 \text { then } \\
m+n \text { is divisible by } 4 \text { " } \\
\text { is correct proposition. } \\
\text { She argued using } \\
\text { several example. }\end{array}$ & $\begin{array}{l}\text { S4 stated that "If both } \\
m^{2} \text { and } n^{2} \text { are divisible } \\
\text { by } 4 \text { then } m+n \text { is } \\
\text { divisible by } 4 \text { " is } \\
\text { incorrect proposition. } \\
\text { She argued using } \\
\text { incorrect reason. }\end{array}$ \\
\hline
\end{tabular}


is different. Furthermore, the different proof comprehension influences a learning strategy for students in order to afford a mathematics proving.

\section{Characteristics of Proof Comprehension and Appropriate Learning in Quadrant I}

Subject S1 has solved the proving task. He knew how to begin the proof. And also, he could connect it to appropriate mathematical concepts well. According to Table 3, Subject S1 could construct a proof in thought-experiment level (Balacheff, 1988;Varghese, 2011) and thought level 2 (Van Dormolen, 1977). This level encouraged student to construct a proof using definition and rigorous logics (Weber, 2004), and also using deductive reasoning and symbolic. Therefore, according to the three worlds, the thinking process of S1 is in axiomatic-symbolic development (Tall, 2010).

According to Table 1 above, characteristics of proof comprehension is a complete comprehension. It indicated that both a local proof comprehension (component 1-3) and a holistic proof comprehension (component 4-7) are complete. Therefore, Subject S1 was able to construct proof correctly. According to Polya (Meel, 2003), this student's understanding is at intuitive level. It showed that in his mind, there are three worlds of knowledge in mathematical understanding, i.e.: applications, meanings, and logical relationship (Lehman, 1977). Meanwhile, following Skemp's understanding, Subject S1 has a relational understanding. And so, type of understanding of the subject is inventing layer (Pirie \& Kieren, 1989). Therefore, proof comprehension in this subject is called completed comprehension.

According to students' characteristics in this quadrant, we suggest that all learning strategy is appropriate for students in the quadrant. Mathematics is not only a subject to be learned and taught, but it is to be produced. However, with hermeneutics, it would be easy to develop our own idea and produce mathematics. Thus, some appropriate learning strategies for students in this quadrant are hermeneutics approach. This was the best opportunity for students to learn from the pioneers how to develop a new idea and create something new. Only with hermeneutics, teaching and learning mathematics and also research in mathematics could be flourishing and fruitful (Djauhari, 2015).
Characteristics of Proof Comprehension and Appropriate Learning in Quadrant II

Subject S2 knew how to begin the proof, but he failed in connecting mathematical concept. According to Table 3, Subject S2 could construct a proof in thought-experiment level (Balacheff, 1988; Varghese, 2011) and thought level 2 (Van Dormolen, 1977). This level encouraged student to construct a proof using definition and rigorous logics and also using deductive reasoning and symbolic.

According to Moore, Subject S2 has difficulty in understanding a concept, so his concept image is not enough for constructing a proof (Moore, 1994). Following Gibson's suggestion, Subject S3 has some difficulties in conceptual understanding, proof techniques and strategies. According to Weber (2004) opinion's, S2's difficulties included their misunderstanding of a theorem or a concept and misapplying it and his inadequate conception knowledge about mathematical proof. Thus, Subject S2's fault is in connecting mathematical concept.

According to Table 1 above, characteristics of proof comprehension is an uncompleted comprehension. It indicated that both a local proof comprehension (component 1-3) and a holistic proof comprehension (component 4-7) are incomplete. According to Polya (Meel, 2003), this student's understanding is at rational level. Meanwhile, following Skemp's understanding, type of understanding of Subject S2 is a relational understanding (Skemp, 1978). Whereas, another suggestion stated that type of understanding of the subject is layer observing (Pirie \& Kieren, 1989). Therefore, proof comprehension in this subject is called uncompleted comprehension.

We suggest that one of appropriate leaning for this quadrant is using the two-column form method. This method can play a dual role, so student can connect some mathematical concept easily. While in many cases teachers do use the form in a way that limits students ability to think flexibly when formulating an argument, in other cases teachers can use the form in a way that enables greater flexibility in reasoning and proving (Weiss, Herbst, \& Chen, 2009).

Besides, students' characteristic is weak validation skill. It indicated that proof comprehension component of "transferring the general ideas or methods to another context" is a wrong validation. Finally, the students 
may not be able to distinguish proofs from supplementary or explanatory and so may not be able to distinguish proofs from supplementary or explanatory comments. It might be good to present material in a way that makes these comments. For example, explanations of definitions, illustrations of relevant concepts, cautionary remarks, and even remarks of proofs, except those needed to organize their linear presentation and help readers with validation, might best be treated as annotations. This might simultaneously provide prototypical examples for enhancing students' conceptions of proof and also encourage them to validate proofs carefully (Selden \& Selden, 1995).

\section{Characteristics of Proof Comprehension and Appropriate Learning in Quadrant III}

Subject S3 didn't know how to begin the proof. According to Table 3, Subject S3 could construct a proof in naïve-empirism level (Balacheff, 1988;Varghese, 2011) and ground level (Van Dormolen, 1977). This level encourage student to construct a proof using inductive reasoning. Therefore, according to Tall, the thinking process of S3 is in embodiment world (Tall, 2010).

According to Moore, Subject S3 has difficulty in understanding a concept, so his concept image is not enough for constructing a proof. Subject S3 has a misunderstanding a theorem or a concept and misapplying it (Moore, 1994). Subject S3 has a difficulty to think deductive reasoning (Recio \& Godino, 2001). And so, these difficulties encourage her to construct a proof using inductive reasoning.

According to Table 1 above, characteristics of proof comprehension is uncompleted comprehension. It indicated that both a local proof comprehension (component 1-3) and a holistic proof comprehension (component 4-7) are incomplete. According to Polya (Meel, 2003), this student's understanding is at inductive level. Meanwhile, following Skemp's term, type of understanding of Subject S1 is instrumental understanding (Skemp, 1978). Whereas, another suggestion stated that type of understanding of the subject is layer image having (Pirie \& Kieren, 1989). Therefore, the proof comprehension in this subject is called uncompleted comprehension.

The students' characteristics have no proof-structure, and also have a little conceptual understanding. One of learning strategies for this quadrant is asking a generate example. Many mathematics education researchers have suggested that asking learners to generate examples of mathematical concepts is an effective way of learning about novel concept (Iannone et al., 2011).

Of course, the students need assistance to refine a proof-structure and conceptual understanding about proposition. Another method is learning using worked-example (Retnowati, Ayres, \& Sweller, 2010; Margulieux \& Catrambone, 2016; McLaren, Van Gog, Ganoe, Karabinos, \& Yaron, 2016)and what kind of assistance to provide, is a much-debated problem in research on learning and instruction. This study presents two multi-session classroom experiments in the domain of chemistry, comparing the effectiveness and efficiency of three high-assistance (worked examples, tutored problems, and erroneous examples. Weber stated that proving is a problem solving activity (Weber, 2005). According to Retnowati et al. that students could understand the material more easily using worked examples than when solving problems. And also, Margulieux and Catrambone stated that worked-example as guided instruction is important for novices because it helps them to organize and use new information more effectively. The students who are unable to construct a formal proof are novice students. Worked-example is example how to proving a proposition, and involved arguments in every step. Worked-example can refine students' knowledge, 1) how to begin a proof, 2) how to understand about end of proof, 3) how to give argumentation for each step, and 4) how to select mathematical concept needed. Point 1) and 2) related to refine proof-structure, in addition point 3) and 4) related to refine a conceptualunderstanding. Therefore, we suggest that the proving process will be generated through this method.

\section{Characteristics of Proof Comprehension and Appropriate Learning in Quadrant IV}

Subject S4 didn't know how to begin the proof, so she failed in beginning a proof. According to Table 3, Subject S4 could construct a proof in thought-experiment level (Balacheff, 1988; Varghese, 2011) and thought level 2 (Van Dormolen, 1977). This level encourage student 
to construct a proof using definition and also using deductive reasoning. Therefore, according to Tall, the thinking process of S4 is in axiomaticsymbolic development (Tall, 2010).

According to Moore, Subject S4 did not know how to use definitions to obtain the overall structure of proofs (Moore, 1994). Following Gibson's suggestion, Subject S4 has difficulties in conceptual understanding and prooftechniques and strategies. According to (Weber, 2004) Weber's opinion, S4' difficulties included their misunderstanding of a theorem or a concept and misapplying it and his inadequate conception knowledge about mathematical proof. Therefore, Subject S4 failed in beginning a proof.

According to Table 1 above, characteristics of proof comprehension is uncompleted comprehension. It indicated that both a local proof comprehension (component 1-3) and a holistic proof comprehension (component 4-7) are incomplete. According to Polya(Meel, 2003), student's understanding is at rational level. Meanwhile, following Skemp's term, type of understanding of Subject S1 is relational understanding. Whereas, following other theory about understanding stated that type of understanding of the subject is formalizing layer (Pirie \& Kieren, 1989). Therefore, proof comprehension in this subject is called uncompleted comprehension.

The students' characteristics have no proofstructure, so that she/he failed in beginning a proof. One of learning strategies for this quadrant is structural method. Among attempts to improve students' proof comprehension in constructing a proof, one can distinguish two broad approaches: (a) changing the presentation of the proof and (b) changing the way a student engages with it (Leron, 1983). The aim of changing the presentation is to make it easier in understanding proof-structure. A structured proof is arranged in levels, with the main ideas and approach given at the top level and subsequent levels giving details and justifications of each of the steps in the preceding levels.

When the presentation is changed, explanations must be provided by the instructor. The explanations can help students who construct incorrect-proof to understand how constructing correct-proof. In terms of Mejía-Ramos et al.'s framework, a structured proof is designed to facilitate understanding higher-level ideas and identifying modular structure, though it does so at the expense of separating some claims from their supporting data and warrant. These changes are reflected in empirical research on the efficacy of structured proofs. Fuller et al. found that, compared to those who read a traditional proof, students who read structured proofs were more successful at summarizing the key ideas of the proof (Fuller et al., 2011). These way can help students who are in Quadrant-IV.

\section{CONCLUSION}

We develop a quadrant model to describe students' classification of proof production. Characteristics of students' proof comprehension in first quadrant are completed comprehension. According to students' characteristics in this quadrant, we suggest that all learning strategies are appropriate for students in the quadrant. Nevertheless, we suggest that appropriate learning strategy for students in this quadrant is a hermeneutics approach. Characteristics of students' proof comprehension in second quadrant are uncompleted comprehension, especially in connecting mathematical concepts and validation skill. We suggest that one appropriate leaning for second quadrant is using the two-column form method. This method can play a dual role, so a student can enable greater flexibility in reasoning and proving.

Characteristics of students' proof comprehension in third quadrant are uncompleted comprehension, especially the difficulty to generate deductive reasoning. The students' characteristics have no proof-structure, and also have a little conceptual understanding. One of learning strategies for this quadrant is asking to generate example and learning using worked-example. Many mathematics education researchers have suggested that asking learners to generate examples of mathematical concepts is an effective way of learning about novel concept. Characteristics of students' proof comprehension in fourth quadrant are uncompleted comprehension, especially in beginning a proof. The students' characteristics have no proof-structure, so that she/he failed in beginning a proof. One of learning strategies for this quadrant is structural method. 


\section{REFERENCES}

Andrew, L. 2009. Creating a proof error evaluation tool for use in the grading of student-generated "Proofs." PRIMUS: Problems, Resources, and Issues in Mathematics Undergraduate Studies, 19(5), 447-462. https://doi. org/10.1080/10511970701765070

Baker, D., \& Campbell, C. 2004. Fostering The Development of Mathematical Thinking: Observations from a Proofs Course. PRIMUS: Problems, Resources, and Issues in Mathematics Undergraduate Studies, 14(4), 345-353. https://doi. org/10.1080/10511970408984098

Balacheff, N. 1988. Aspects of Proof in Pupils' Practice os School Mathematics. Mathematics, Teacher and Children, 216235.

Djauhari, M. A. 2015. Hermeneutics in teaching and learning mathematics: Revitalising mathematics education. ASM Science Journal, 9(2), 1-8.

Fadillah, S., \& Jamilah. 2016. Pengembangan Bahan Ajar Struktur Aljabar Untuk Meningkatkan Kemampuan Pembuktian Matematis Mahasiswa. Jurnal Cakrawala Pendidikan, 1, 106-113.

Fuller, E., Mejía-Ramos, J. P., Weber, K., Samkoff, A., Rhoads, K., Doongaji, D., \& Lew, K. 2011. No TitleComprehending Leron's structured proofs. In S. Larsen, K. Marrongelle, \& M. Oehrtman (Eds.), Proceedings of the 15th Annual Conference on Research in Undergraduate Mathematics Education (pp. 84-102).

Iannone, P., Inglis, M., Mejía-Ramos, J. P., Simpson, A., \& Weber, K. 2011. Does generating examples aid proof production? Educational Studies in Mathematics, 77(1), 1-14. https://doi.org/10.1007/ s10649-01

Larsen, S., \& Zandieh, M. 2008. Proofs and refutations in the undergraduate mathematics classroom. Educational
Studies in Mathematics, 67(3), 205-216. https://doi.org/10.1007/s10649-0079106-0

Lee, K. S. 2016. Students' proof schemes for mathematical proving and disproving of propositions. Journal of Mathematical Behavior, 41, 26-44. https://doi. org/10.1016/j.jmathb.2015.11.005

Lehman, H. 1977. On Understanding Mathematics, 27(2), 111-119.

Leron, U. 1983. Structuring Mathematical Proofs. The American Mathematical Monthly, 90(3), 174-185. https://doi. org/10.2307/2975544

Margulieux, L. E., \& Catrambone, R. 2016. Improving problem solving with subgoal labels in expository text and worked examples. Learning and Instruction, 42, 58-71. https://doi.org/10.1016/j. learninstruc.2015.12.002

McLaren, B. M., Van Gog, T., Ganoe, C., Karabinos, M., \& Yaron, D. 2016. The efficiency of worked examples compared to erroneous examples, tutored problem solving, and problem solving in computerbased learning environments. Computers in Human Behavior, 55, 87-99. https:// doi.org/10.1016/j.chb.2015.08.038

Meel, D. 2003. Models and Theories of Mathematical Understanding : Comparing Pirie and Kieren's Model of Growth of Mathematical Understanding and APOS Theory. CBMS Issue in Mathematics Education American Mathematical Society, 12.

Mejia-Ramos, J. P., Fuller, E., Weber, K., Rhoads, K., \& Samkoff, A. 2012. An assessment model for proof comprehension in undergraduate mathematics. Educational Studies in Mathematics, 79, 3-18. https:// doi.org/10.1007/s10649-011-9349-7

Moore, R. C. 1994. Making the transition to formal proof*. Educational Studies in Mathematics, 27, 249-266. 
Pirie, S., \& Kieren, T. 1989. A Recursive Theory of Mathematical Understanding. For the Learning of Mathematics, 9(3), 7-11. https://doi.org/10.2307/40248156

Recio, A. M., \& Godino, J. D. 2001. Institutional and personal meanings of mathematical proof.Educational Studies in Mathematics, 48, 83-99. https://doi.org/10.1017/ CBO9781107415324.004

Retnowati, E., Ayres, P., \& Sweller, J. 2010. Worked example effects in individual and group work settings. Educational Psychology, 30(3), 349-367. https://doi. org/10.1080/01443411003659960

Selden, A., \& Selden, J. 2003. Validations of proofs considered as texts: Can undergraduates tell whether an argument proves a theorem? Journal for Research in Mathematics Education, 34(1), 4-36. https://doi.org/10.2307/30034698

Selden, J., \& Selden, A. 1995. Unpacking the Logic of Mathematical Statements. Educational Studies in Mathematics, 29(2), 123-151.

Skemp, R. R. 1978. Relational Understanding and Instrumental Understanding. The ArithmeticTeacher, 26(3),9-15.https://doi. org/10.1017/CBO9781107415324.004

Sowder, L., \& Harel, G. 2003. Case studies of mathematics majors' proof understanding, production, and appreciation. Canadian Journal of Science, Mathematics and Technology Education, 3(January 2015), 251-267. https://doi. org/10.1080/14926150309556563

Stylianides, G. J., \& Stylianides, A. J. 2009. Facilitating the Transition from Empirical Arguments to Proof. Journal for Research in Mathematics Education, 40(3), 314352. https://doi.org/10.2307/40539339

Syamsuri, Purwanto, Subanji, \& Irawati, S. 2016. Characterization of students formal-proof construction in mathematics learning. Communications in Science and Technology, 1(2), 42-50.
Syamsuri, Purwanto, Subanji, \& Irawati, S. 2017. Using APOS Theory Framework: Why Did Students Unable to Construct a Formal Proof? International Journal on Emerging Mathematics Education, 1(2), 135-146.

Syamsuri, \& Santosa, C. 2017. Karakteristik pemahaman mahasiswa dalam mengonstruksi bukti matematis. Jurnal Review Pembelajaran Matematika, 2(2), 131-143. https://doi.org/https://doi. org/10.15642/jrpm.2017.2.2.131-143

Tall, D. 2010. Perception, Operations and Proof in Undergraduate Mathematics. Community for Undergraduate Mathematics Sciences Newsletter University of Auckland, pp. 21-28.

Tall, D., Yevdokimov, O., Koichu, B., Whiteley, W., Kondrieteva, M., \& Cheng, Y. H. 2012. Cognitive Development of Proof. In G. Hanna \& M. De Villiers (Eds.), Proof and proving in mathematics education, The 19th ICMI Study (pp. 13-49). New York: Springer. https://doi.org/10.1007/978-94007-2129-6

Van Dormolen, J. 1977. Learning to Understand What Giving a Proof Really Means. Educational Studies in Mathematics, 8(1), 27-34.

Varghese, T. 2011. Balacheff's 1988 Taxonomy of Mathematical Proofs. Eurasia Journal of Mathematics, Science \& Technology Education, 7(3), 181-192.

Weber, K. 2001. Student Difficulty in Constructing Proofs: The Need for Strategic Knowledge. Educational Studies in Mathematics, 48(1), 101-119.

Weber, K. 2004. A framework for describing the processes that undergraduates use to construct proofs. In Proceedings of the Annual Meeting of the North American Chapter of the International Group for the Psychology of Mathematics Education (Vol. 4, pp. 425-432). 
Weber, K. 2005. Problem-solving, proving, and learning: The relationship between problem-solving processes and learning opportunities in the activity of proof construction. Journal of Mathematical Behavior, 24, 351-360. https://doi. org/10.1016/j.jmathb.2005.09.005

Weber, K., \& Alcock, L. 2004. Semantic and syntactic proof productions. Educational Studies in Mathematics, 56, 209-234. https://doi.org/10.1023/ B:EDUC.0000040410.57253.a1
Weiss, M., Herbst, P., \& Chen, C. 2009. Teachers Perspectives on "Authentic Mathematics " and the Two-Column Proof Form. Educational Studies in Mathematics, 70(3), 275-293. https://doi.org/10.1007/ s10649-008-9144-2 